\title{
FROM SPIRITUALISTIC TOWARD MORE PRAGMATIC PATTERN: RE-ORDERING BALINESE HOUSES AND VIABILITY OF THE HOUSEHOLD TRADITIONS IN TOURISM ECONOMY
}

\author{
I Dewa Gede Agung Diasana PUTRA ${ }^{1, *}$, Mirjana LOZANOVSKA ${ }^{2}$, Robert FULLER ${ }^{3}$ \\ ${ }^{1}$ Department of Architecture, Engineering Faculty, Udayana University, Indonesia \\ ${ }^{2,3}$ School of Architecture and Built Environment, Deakin University, Australia
}

Received 07 July 2018; accepted 28 February 2019

\begin{abstract}
The traditional Balinese house, manifested and translated in an agricultural context, has roles to accommodate domestic and socio-cultural activities. Once the house accommodates tourist activities as an additional function, many parts of the house are transformed. The transformation presents a conflict between economic gain and the preservation of Balinese traditions in the house. In order to illustrate this paradoxical phenomenon, this paper first shows how the traditional house has been reconfigured as a response to address the specific challenges of the tourist economy. Then, using architectural examination and interviews, the paper shows that the infiltration of the tourist activities has blurred the house's configuration so that the transformed house is no longer able to express its original characteristics, hierarchy values and symbolic meaning.
\end{abstract}

Keywords: tourism, transformation, the traditional Balinese house, household traditions, identity, pattern.

\section{Introduction}

The traditional Balinese house is organized to accommodate socio-cultural and religious practices that have been produced and created as a part of the Balinese identity (Tan, 1967; Hobart, 1978; Hobart, Ramseyer, \& Leemann, 1996). In this context, the ritual position and movement are the significant elements to set the traditional house (Hobart, 1978). In this context, the house, as an architectural production, is a key maker of authenticity (Allerton, 2003). However, since the culture of Bali has been seen as an economic resource for tourism development in the early twentieth century, the culture, including the traditional Balinese house, has become a resource of not only admiration but also commodification and change. In the context of a tourist economy, the transformation is a paradoxical phenomenon. On the one hand, the traditional house, where the Balinese perform their socio-cultural and religious practices and culture, is a resource to attract tourists. On the other hand, the house has been transformed by new structures which have been constructed in the adjacent spaces to or by demolishing existing pavilions. Therefore, its traditional configuration and form have changed. This poses an architectural challenge of how to accommodate traditional domestic and socio-cultural activities and, at the same time, to gain economic benefits by accommodating tourist activities (Figure 1).

A tradition, however, is not a static phenomenon but a process of gradual transformation in which it cannot simply repeat the ideas of the past (Eisenstadt, 1973; Gusfield, 1967; Williams, 1983; Clifford, 1994). Balinese traditions and culture, in an agricultural context, were also the result of a gradual transformation. The transformation consisted of selective adoption, where the new was filtered, adjusted
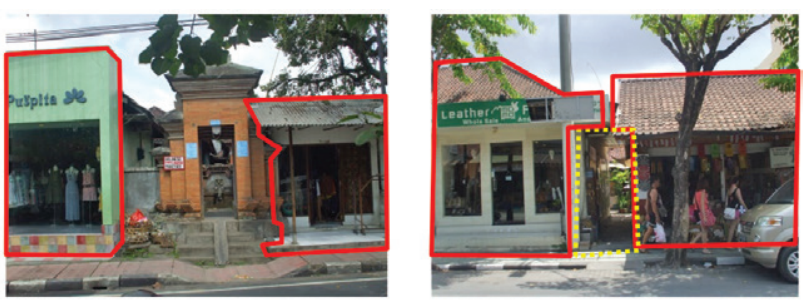

Figure 1. The Traditional Balinese house hides behind the tourist facilities. The angkul-angkuls (the traditional gates) as a traditional house identity are among tourist facilities (source: authors)

${ }^{*}$ Corresponding author. E-mail: diasanaputra@unud.ac.id 
and modified to meet the needs and conditions of the Balinese (Geriya, 2007; Mantra, 1993; Nordholt, 1986). The ancient Balinese traditions, such as the spirits of nature and ancestors, family systems and spatial orientations, can still be important components of religious activities in present-day practices (Lansing, 1983; Swellengrebel, 1984; Nordholt, 1986). In this context, the traditions and culture can be seen as a resource to create boundaries and identity (Derek \& Japha, 1991; Hall, 1990; Proshansky, Fabian, \& Kaminoff, 1983).

However, in the tourist economy, the indigenous population of Bali uses their traditions and culture, inspired by the Hindu Balinese religion, as an asset. This modern-capitalistic pressure has transformed the daily life of people in a community (Suprapti, Kistanto, Pandelaki, \& Indrosaptono, 2017) in which people have a potent to lose their traditional practices (Ekhaesa, Amole, \& Martins, 2018). Many scholars stated that the tourism industry, as a modern-capitalistic pressure, has negative impacts, such as the degradation and commercialization of culture including architecture (Hanna, 1972; Bugnicourt, 1977; Picard, 2003; Achmadi, 2007; Cohen, 1978; Nas, 1997). On the other hand, some others suggested that there is an interrelationship between tourism development and culture, and more precisely the awareness of cultural distinction. In this sense, tourism has supported cultural preservation, and its development has stimulated the awareness of the people to preserve the richness of their culture, is an argument made by some scholars in the field (Sanger, 1989; Dogan, 1989; Hitchcock, King, \& Parnwell, 1993; McKean, 1973). These two sides of argumentation show that there are endless debates about the impacts of tourism on the local culture. In Bali, the tourist economy has led to the transformation of the traditional house. New structures have been built for tourist facilities in the house, thus altering the spatial configuration of the existing structures. The new additional functions present a conflict between economic gain and the preservation of Balinese traditions in the houses. The new agenda for the house is proving to be a challenge and creates a tension in relation to the maintenance of the traditions as a continuity of Balinese culture.

This paper investigates and explores how the Balinese house has been reconfigured as a response to address the specific challenges of the tourist economy. To do this, the paper examines traditional houses transformed for tourist facilities in four selected villages in Bali. It uses architectural examination and spatial stories of people's activities as a method of investigation. This method involved architectural documentation, graphic analysis and narratives of people's cultural activities. Through this method, the changes of houses' setting, religious activities and social practices were scrutinized and presented. Initially, however, some theoretical considerations of how traditions in general are transmitted are discussed. This is followed by a detailed description of the elements of the traditional Balinese house. The method and details of the investigation are then presented. In subsequent sections, the paper explores how the traditions and rituals have been transformed by the new arrangements within the house. Some conclusions are presented in the final section.

\section{The transmission of traditions}

As a part of socio-cultural and religious practices of people, tradition is not a fixed entity but it can be defined as a process of gradual transformation (Eisenstadt, 1973) and can be historically unfinished (Clifford, 1994). A transmission tradition refers to the idea of people's responses to the old tradition. These responses are influenced by not only the interactions of members of a society with foreign culture but also the growth of social and cultural movements. In these interactions, some traditions are accepted only after being scrutinized to determine whether they meet with certain criteria in a society. The old might be adjusted so that it meets new conditions or the old is used for new purposes (Hobsbawn, 1983). This analytical process of acceptance, adaptation and even rejection implies that it changes over time. Its changing nature constitutes a connection between "an invented present" and an "imagined past" through which there is an ongoing process of transformation (Wood, 1993, p. 58) and it continually undergoes a process of renewal and modification (Hoben \& Hefner, 1991). The transmission process involves the connection between the past and the present in which current traditions contain "memory" or "the record of the past" as a medium to maintain the link and to bring past icons as substances of "present attachment" (Shils, 1981, p. 50). However, the changing nature of tradition is never absolute or extreme as that would constitute an end to the tradition.

Like other traditions, the memory of past icons can be made available in present objects such as buildings. The durability of their materials and the existence of the building pattern are the factors that demonstrate and present the past in the current building practices (Shils, 1981). The impression of traditions in contemporary building practices are still included since architectural traditions offer "profitability, convenience, and desired opportunities" to the people (Shils, 1981, p. 67). Buildings, including the house, continue as traditions inherited in various stages of adaptation, modification and replacement. Shils' theory about the transmission process of traditions is very important in order to understand the transmission of traditions in the traditional Balinese house, since their traditions have undergone a process of continuous renewal over time (See Nordholt, 1986; Vickers, 1989; Mantra, 1993).

As a part of architectural production, a house, which is the result of the traditions of building practices in a community, undergoes a process of transformation over time. This transformation process parallels the change and continuity of the values and beliefs of a society. The values and beliefs are translated into shapes, spatial order and forms in an architectural product. The house is a physical form representing the demands, values, desires, dreams and passion of people in their environment (Rapoport, 
1969; Redfield, 1965). The builders of traditional architecture are customarily from the communities and the process of building is learned by each successive generation (Oliver, 1998). Challenges, faced by many generations in different communities including societies of Southeast Asia (Sparkes, 2003), to address novel problems, modernization and technological changes have caused adjustments in the construction of the house. Based on Shils's theory $(1971,1981)$, this involves analyzing and evaluating where the old traditions are modified in the process of transmission to meet their new conditions.

A culture is comprised of whole complex of distinctive spiritual, material, intellectual and emotional features (UNESCO, 1982). The distinctiveness has become the identity of a community that expresses a commonality of tradition and culture among the members of a society and an otherness, or sharp distinctiveness, from non-members. The character of some groups within a society may differ although they live in similar natural conditions. People have different ways of responding to the environmental conditions and the natural resources in their society. These differences cause a variation of forms (Oliver, 1998; Rapoport, 1969). This variation can be seen in some traditional houses that have different cultural values and beliefs even though they exist in the same geographic condition. Different societies of Southeast Asia, for example, offer an incredible range of religions, kinship systems, as well as architectural forms (Sparkes, 2003). The differences portray an identity and create distinctiveness from others. The variation of the traditions creates uniqueness that both offers a sense of dignity but also can, in some circumstances, provide an income for the communities when responding to tourism (Grunewald, 2002).

Since becoming aware of its economic value, people have utilized their culture as an asset for tourism development. Cultural tourism is generated by the motivation of many tourists to search for exotic cultural experiences that consist of artifacts, performances and other products of traditional ethnic groups (Yang, Wall, \& Smith, 2006). Based on this phenomenon, many countries promote and try to maintain their culture as resources to create centers of tourist attraction (Yang \& Wall, 2009; Ivkovska, 2016). This is a paradoxical phenomenon where, as products of change and non-static phenomenon, cultural practices in tourist destinations undergo a process of gradual transformation. Central to this paradox is the discussion of the cultural transformation process in tourist destinations to understand the impact of tourism. There are many conflicts between meeting the needs of tourists as a strategy to gain an economic benefit and maintaining culture as an expression of identity. To understand these conflicts, it is necessary to appreciate how the traditional Balinese house is configured and what this represents.

\section{The traditional Balinese house}

The traditional Balinese house is organised within the framework of ritual position and movement that possess a complex significance (Hobart, 1978). The use of spaces presents the spiritual symbols of rituals procession and location. Central to these spiritual symbols, which are the prominent aspect in the space layout in Bali (Nas, 2012), are that many spaces are interrelated and are widely understood to be spaces with different levels of sacredness (Hobart, 1978; Tan, 1967). Based on a cosmological philosophy in which humans and the universe are regarded as unity, the house is likened a world that is built upon opposite poles: the divine and the nether forces. The upper world is the sacred direction and the under or nether world is the profane (Eiseman, 1989).

In this spiritual symbols, the sacred direction is situated in the highland/mountains called kaja. The opposite direction, which is less sacred or even impure, is kelod meaning the seaward. In between the upper and nether worlds lies the intermediate sphere called madyapada/ mertyapada (Swellengrebel, 1984). This intermediate sphere is the space for humans, which have important roles to maintain the harmonious relationship with upper world that is related to God, other human beings and the environment as a representation of the nether worlds (Hobart, Ramseyer, \& Leeman, 1996). These roles are the embodiment of the Hindu religious philosophy called tri hita karana, which is widely accepted in Bali (Ashrama, Pitana, \& Windia, 2007). The harmonious relationship with God, other human beings and the environment is performed in respectively pahrayangan, pawongan and palemahan zones (Dalem, 2007). This philosophy is implemented in the house that is not only reflected by the three similar elements, called tri angga: utama, madia and nista. Therefore, pahrayangan is utama, the most sacred value, that is like a head; pawongan is madia (intermediate sphere) or the body that means middle or neutral; and palemanahan is nista or the legs mean below or most profane value (Gelebet, 1986). In architecture and settlement design, the tri hita karana and the tri angga concepts are used to establish the divisions within the house.

The traditional Balinese house is perceived and interpreted through the religious and spiritual concepts outlined above. The three parts in the house are interrelated and inseparable, and interpreted in a similar way to the division of the village where, as suggested by Covarrubias (1974, p. 42), the pahrayangan or head and the pawongan or body are the "dwelling-ground" and the palemahan or legs are the "unlived" parts (Figure 2). As a most profane value, palemahan or legs are uninhabited by humans, so there is no particular traditional order through which to arrange the configuration of vegetation and animals. In contrast, The most sacred value (pahrayangan or head) and neutralvalue (pawongan or body), designed to accommodate domestic and socio-cultural activities, are regulated based on traditional concepts that are described in the manuscript of the traditional Balinese architecture called asta kosala-kosali (Puja, 1986).

Based on the Balinese manuscript (asta kosala kosali), the family temple is the most sacred area (indicated a) (Figure 3). In this location called merajan, people build shrines in such a way so that the space is able to ac- 
commodate many ceremonial activities dedicated to God and ancestors. The compound space is the intermediate sphere where the people build many pavilions (bales) to accommodate domestic and ceremonial activities related to human lifecycle ceremonies. This part consists of the northern pavilion called bale daja (indicated $b$ ), the eastern pavilion called bale dangin/bale adat (indicated $c$ ), the western pavilion called bale dauh (indicated $d$ ), the granary called jineng (indicated $e$ ), the kitchen called paon (indicated $f$ ), the courtyard called natah (indicated $g$ ). The palemahan is the nista (nether) area, also called lebuh. The palemahan consists of a backyard called teba and a front part of the house consisting of telajakan, walls, an angkul-angkul and an aling-aling. The aling-aling (indicated $h$ ) is a small wall behind the traditional gate called angkul-angkul (indicated $i$ ). The profane space between the front wall and road is telajakan (indicated $j$ ). This place functions as a garden where people plant vegetation such as flowers, foliage and trees; and keep chickens in cages, especially in the afternoon when people return from rice fields. The backyard called teba (indicated $k$ ) is a place for planting vegetation and raising animals that are used for food and offering materials. It is also a place for garbage processing and a place to prepare offerings related to ceremonial activities, including many kinds of food and other ceremonial equipment.

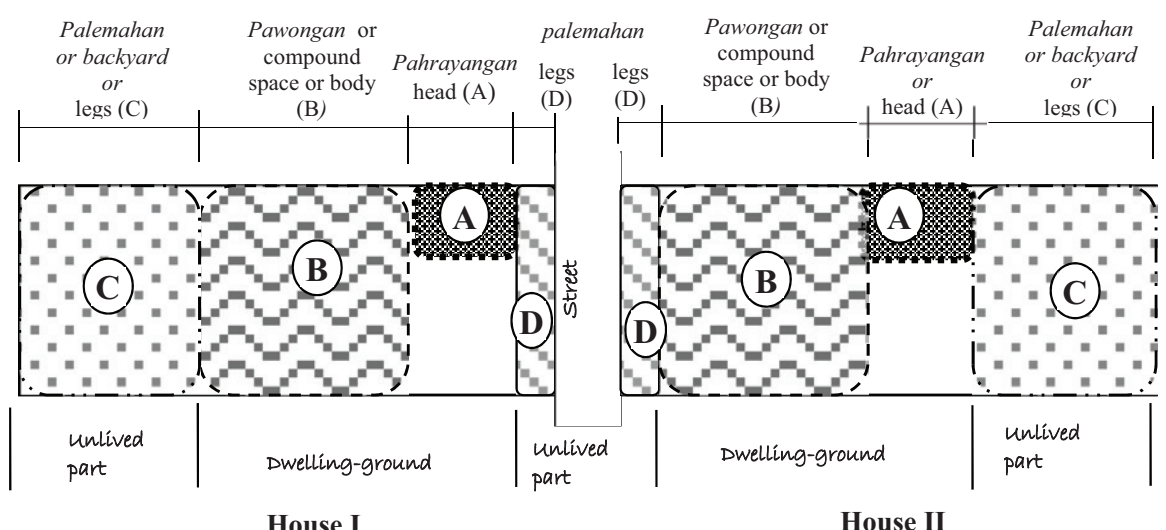

Kaja (toward mountain)

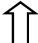

Legend
A. Family temple zone (merajan)
C. Backyard (teba)
B. Compound space (bales and natah)
D. Front part (telajakan, angkul-angkul and aling-aling)

Figure 2. The division of the traditional Balinese house (source: authors)

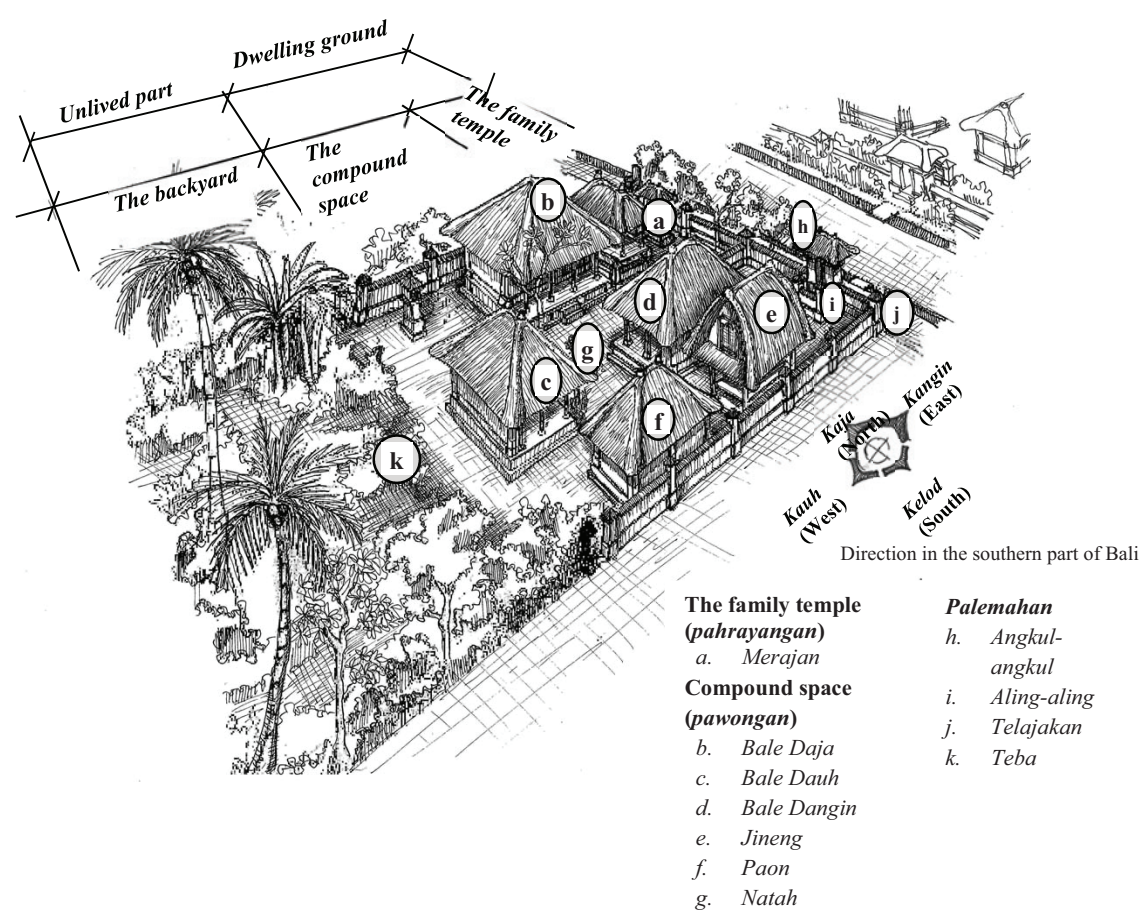

Figure 3. Typical configuration of the traditional Balinese house (source: authors) 
Related directly to the teaching of the Hindu religion, pavilions and spaces in the traditional Balinese house are designed to accommodate domestic and socio-cultural activities. The Balinese perform ceremonial activities in the house including a sanggah/merajan (the family temple), pavilions called bale and the courtyard called natah. The dewa yadnya consists of many ceremonial activities associated with God and the ancestors such as odalan (the regular festival in the family temple to celebrate the anniversary of its dedication), galungan and kuningan (to celebrate the victory of good over evil) and saraswati (to celebrate knowledge). These activities are mainly performed in the family temple (Figure 4).

Manusa yadnya is ceremonies that are connected with humans from rebirth, birth and life, while pitra yadnya are ceremonies that are connected with dead bodies and their souls (Hobart, Ramseyer, \& Leeman, 1996). Therefore, the manusa and pitra yadnya ceremonies are related to the human life cycle: birth-life-death-rebirth. The rituals are performed in a house and spaces in a village. Every ceremony has different ritual processes and uses many parts of the house. The natah and bale adat (a pavilion for ceremonies) are main spaces for performing such ceremonies (Figure 5). To support the ceremonies and display offerings, temporary bamboo structures such as tetaring (a temporary structure to protect a courtyard from sunlight), pemiosan (a place for a high priest to lead ceremonies) and petak (a place for offerings in a purification of soul ceremony called nyekah, a ceremony categorized as pitra yadnya ceremonies) are built in the natah or teba.

The ceremonial activities show that the house is built to address a complex set of purposes and is greatly in- fluenced by the cultural activities. A mixture of offerings, music, dance performances and architectural elements are a spiritual and aesthetic act in the house. Ritual and spatial practices blur the boundaries between pavilions (bales) and open spaces, and between pavilions (bales) and temporary bamboo structures. It is evident that there is an intimate interconnection and interrelationship between spaces and rituals in an architectural production (McLendon, 2013). Therefore, the transformation of spaces in the house is likely to influence the positions and movements of the rituals that are investigated in this paper.

\section{Method: investigating the transformation of the houses}

The spaces are not merely buildings consisting of walls and a roof, but the area where the people live and conduct their activities (Quantrill, 1974), in which occupants inhabit and interweave the spaces and become part of the house. However, the tourist economy has encouraged people to transform their traditional houses. Field research revealed that many traditional Balinese houses have been transformed for tourist facilities such as homestays, art shops and restaurants (Putra, Lozanovska, \& Fuller, 2017). Along the main roads in the four selected tourist villages of Kuta, Sanur, Ubud and Kamasan, traditional settlements were previously represented by the presence of traditional walls and gates, but now many of these have been transformed by tourist facilities. Using base line data collection in the four villages, $54 \%$ of the 749 traditional Balinese houses have been transformed into tourist facilities (Putra, Lozanovska, \& Fuller, 2013,
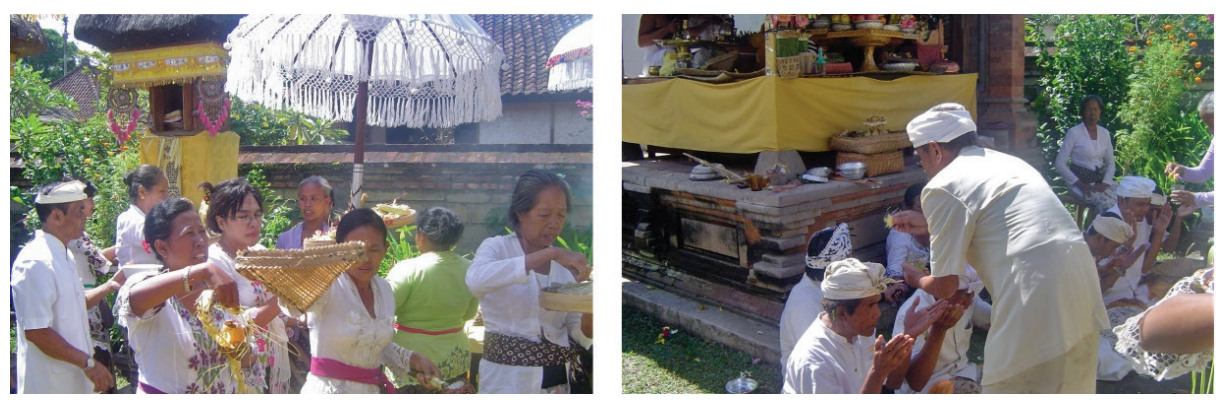

Figure 4. A ceremonial activity associated with God and ancestor in a family temple (source: authors)

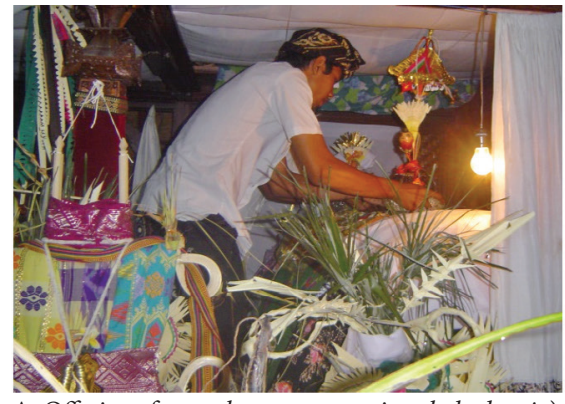

A. Offerings for ngaben ceremony in a bale dangin)

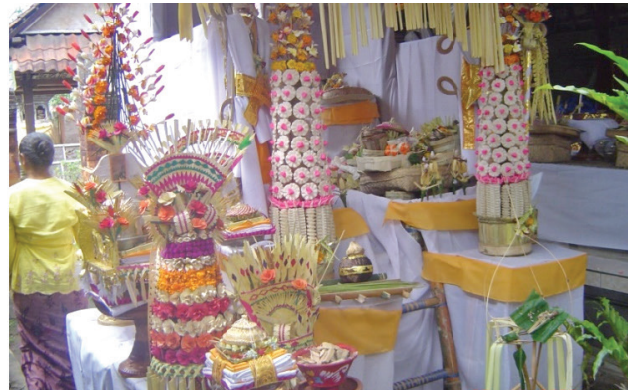

B. Offerings for nyekah ceremony in a petak in a natah ceremony

Figure 5. Offerings in the bale dangin (A) and natah (B) (source: authors) 
2017). These data show that tourist activities had significantly influenced the transformation. In the transformed houses, new pavilions were built not only adjacent to the existing buildings but also after demolishing the existing pavilions, enabling enlargement and multiplicity of new structures in the house. The enlargement or multiplicity causes the platforms, on which to perform traditions and maintain the continuity of religious activities, social practice, have changed.

To understand and examine the adjustment of the activities, and the viability of the household traditions, this paper investigates whether or not the transformation influences the functions and characteristics of the house. Architectural documentation, including plans and photographs was the basis on which existing traditions were inscribed. Architectural documentation was not merely an artificial and additional component rather it was a way of investigating the architectural challenge in the transformation. It was used to trace a narrative of architecture's entanglement with and dependence on the cultural activities and spatial practices of occupants (Lozanovska, 2002).

Architectural plans, for example, illustrated not only the physical transformation and reconfiguration of the traditional Balinese house, but also spatial stories and narratives of people's activities and memory in the house. As explained by Harvey (2014, p. 376), these spatial stories are to "uncover and reconstruct the experiences of the people." Architectural plans were used to consolidate memory and to reconstruct the history of the house. Through graphic analysis of physical transformation in plans and by interviewing the heads of the households, the changes of religious activities and social practices in the house were investigated and represented. Prior to each interview, architectural drawings of recent configurations were made by observing, measuring, documenting and then transferring to paper. These building configurations were used as basic data to reconstruct the "biography of the land" (Orlando, 2014) and historical spatial setting.

\section{Transformation of the traditional Balinese house}

\subsection{The physical transformation}

Balinese culture, as suggested by many studies such as Geriya (2007) and Mantra (1993), has been the result of the reactions and communications of the Balinese people with people from other cultures over many generations. The transformation has deeply influenced the process of accepting new traditions, based on religious belief and practice, social structure and political condition (Nordholt, 1986; Vickers, 1989; Picard, 1996). These factors has caused the variation of not only the process of handing down traditions but also receiving and recommending. This process presents that the traditional Balinese house is not as static and frozen entity but it experience ongoing transformation and transitaory (Suartika, 2013).

In this transformation process, material production, political and economic factors are significant to determine the values and forms of architecture (MacRae, 2011). Related to this, building materials are a component of traditional architecture that express the otherness in Bali. The architectural style of Badung called bebadungan that uses brick for all parts of the building, for example, had different form from the style in Gianyar called gegianyaran, that use a combination of brick and sandstone as building materials. In general, the form of the building was similar, but because of the character of the building materials, there were some differences in the ornaments and part of the building forms. This character has presented an identity and created distinctiveness from the others.

As a cultural phenomenon, an identity also changes over time. It is transformed through interaction, both inside and outside of the group community (Logan, 1994). Advanced building materials and technologies has been also adopted as a part of the traditional architecture. The adoption has caused the variation of building forms and expression (Nas, 1999). In this context, the traditional architecture undergoes a continuous evolution (Vale, 1992) where the use of images of modernity that is shown through new materials and shape express a new identity (Rapoport, 1983). This transformation process is called an architectural hybrid related to the use of modern architectural aspects in the traditional Balinese architecture or vice versa (Wijaya, 2003). Taman Ujung Karangasem and bale bandung/ loji/kantor have presented that the traditional Balinese architectural hybrid has adopted other cultures as a part of the identity of the traditional Balinese architecture. Present building technologies have also caused the building form in Bali in which new building technologies have given opportunities for the people to construct multy storey buildings in their house.

The transformation of space and architecture in Bali is related to political agenda in Indonesia (Kusno, 2000, 2010). The adoption of other cultures into the Balinese architecture was influenced by ethnic policies of the Dutch colonial administration and the Indonesian Government. As suggested by Kusno (2000), the Dutch combined an ambition to modernise Bali and an aspiration to preserve the Balinese architectural style. The form of the preservation agenda has been continued by the Indonesian Government in which Bali was promoted and conserved as a site of traditional culture of Indonesia. The culture centrally hinged on a representation of a regional architectural variance as an object opposed to modern architecture (Kusno, 2000). The Indonesian Government reinterpreted the Balinese architecture as a different ethnicity with other regions in Indonesia. Therefore, the political agendas in Bali have produced architectural variation. The variation of the traditional architecture has operated as an idea of uniqueness that offers a sense of dignity and a cash income for the Balinese from tourism. However, since the people are aware of its economic value, people have utilised their culture as an asset for tourism development.

The development of tourism has influenced many aspects of the village, including the traditional Balinese house. Along the main roads in the villages, traditional settlements 
were previously represented by the presence of traditional walls, gates, and the spaces between the wall and the road. Now many of these have been turned into tourist facilities such as home-stays, art shops, restaurants, cafes, moneychangers and laundries. Some others have been transformed to be garage presenting the people's new demand. The other front component of the house is the traditional gate (angkul-angkul), which is the visual identity of the house. From the gates, people can easily identify the presence of a group of traditional houses. However, many angkul-angkuls have vanished so that it is hard to recognize the presence of the houses behind those facilities.

Every division of the house has undergone transformation. The most sacred space in the house, where God and occupants' ancestors reside, underwent fewer and more limited transformations. Only a few family temples have been relocated to other parts of the house, or elevated to the higher level of a new structure (Putra, Lozanovska, \& Fuller, 2017). This phenomenon has been found in many areas in Bali in which this relocation has changed the ordering of spaces system where the horizontal hierarchy of spaces has been undermined and changed into a vertical hierarchy system (Danes, 2001).

On the other hand, new structures have been built in a backyard and compound pavilions. New constructions were built adjacent to and by demolishing existing pavilions to accommodate not only tourist activities but also an increase in family size. These constructions utilised parts of the natah so that its size, form and setting were transformed. Moreover, the backyard, where people planted any kind of vegetation and raised animals, has now become a place for domestic and tourist facilities. The limitation of space has forced people to live in the most profane areas of the house, which was a place for vegetation, animals and garbage processing, based on traditional guidelines. The transformation has also influenced by the urban's building-forms in which because of the density of the need of spaces and building technology, the new buildings are constructed in two or more storey construction.

\subsection{Rituals in the new setting of the house}

The spaces that were organized according to definite rules within the framework of ritual arrangement are mostly ordered to accommodate the contemporary demands of occupants under the external force of tourism. Cultural commoditization of the house has encouraged or shaped the value of the potential local practices and has inspired the way local people modify their house. The house configuration has been altered into more flexible functions and definitions. This paper found that the reduction of ritual spaces has reduced religious activities. In some houses, it was found that some rituals are no longer performed, while some other rituals, which were carried out in particular spaces, are now performed in unusual spaces. This new setting presents a deterioration of the traditional house as a stage for rituals.

\section{a. Transformation of the Family Temple: the pahrayangan as the most sacred space}

The family temple is the most sacred place in the house. It was arranged in such a way so that the religious atmosphere in the family temple was able to be experienced and witnessed by all occupants in many parts of the house (Figure 6). It was like a stage on which religious performances were presented not only for God and the ancestors but also for all congregations. People who had particular tasks in the ceremonies sat on the ground of the family temple and sang religious songs. Some women, wearing traditional clothes, performed rituals by laying offerings and incense and sprinkling holy water on the shrines (see also Figure 4). The activities are like a "theatre" (de Certeau, 1984) in which this "theatre" described and presented a general trajectory of people's religious faith (Geertz, 1984).

On the other hand, pavilions or the courtyard were spaces for spectators in the religious festival i.e. they were sites from which people who were not involved in the procession of rituals could witness the rituals and experience the sacredness of the atmosphere. The sacredness was not experienced only by listening to the sacred sounds from a priest's bell and religious songs, but also by witnessing the procession from the outside. Visually, the low walls of the family temple created a virtual border so that the movements of ceremonial activities became a stage of artistic performances.

However, tourism has changed this order especially when few family temples ( $8 \%$ of the 132 houses in Kuta, $8 \%$ of the 60 houses in Sanur and 5\% of the 129 houses in Ubud) were relocated onto the upper floor (Figure 7)
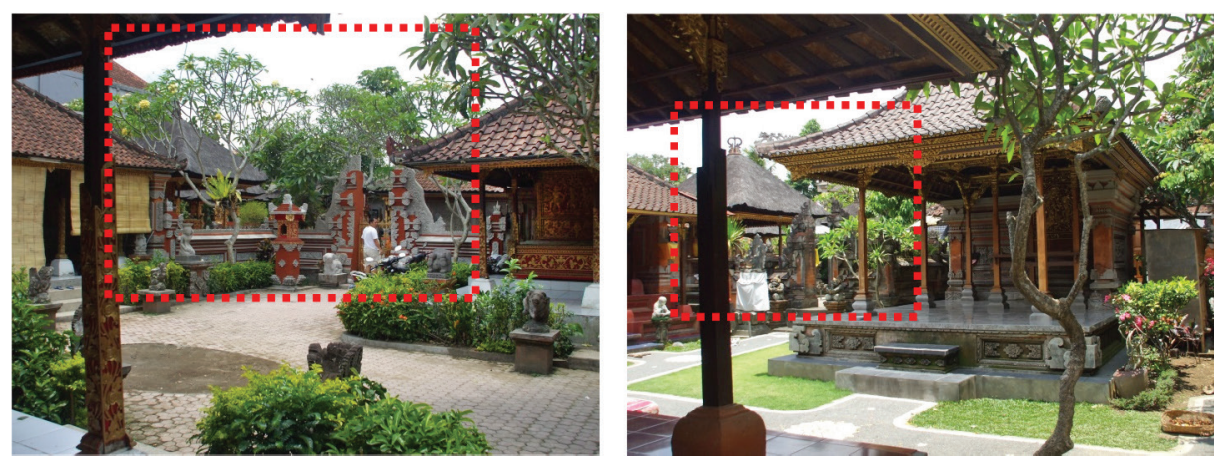

Figure 6. Sample the family temples from the courtyard in traditional houses (see the red dashed line) (source: authors) 


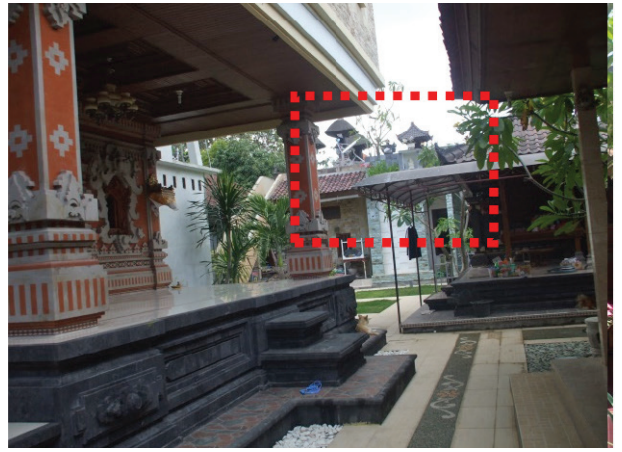

Figure 7. Sample of family temples relocated to the second floor in transformed houses (see the red dashed line) (source: authors)

(Putra, Lozanovska, \& Fuller, 2017). Although the transformed family temple still consists of shrines as in the old configuration, the new setting is far from presenting an intimate interconnection with other spaces. Rather, it might become an isolated space and a separate layer. In this setting, through interviewing the owners, a realm of religion and sacred rules are performed as usual. These religion activites are a medium to maintain the link and "the record of the past" in present traditions (Shils, 1981, p. 50). However, the occupants who stand or sit outside the family temple are not able to witness the procession of ceremonies visually.

The unusual location of the family temple has created a paradox. The relocation of the family temple to the top floor has produced a separation of the sacred sense of religious practices in which this sense cannot be experienced by people in other spaces in the house. The relocation also creates a layer differentiation and a strong boundary between the family temple and the body of the house in which, in order to observe the activities, people must enter the family temple.

\section{b. Transformation of the compound space: the pawongan}

The compound spaces provide spaces to accommodate domestic and religious practices especially related to manusa and pitra yadnya ceremonies. The crucial actions in the ceremonies are that each ritual detail should be performed in proper ways so that congregations will avoid negative supernatural consequences (Geertz, 1973). For Balinese, ceremonial rituals are important to give thanks to God and ancestors and to avoid negative impacts from supernatural forces. However, the novel condition of spaces has encouraged the adjustment and relocation of rituals. Based on spatial stories and narratives of occupants' activities and memory in the house, many ceremonies related to panca yadnya, including ceremonies for a baby, toothfiling and wedding, are still performed in the houses, albeit with some adjustments.

The reconfiguration of the traditional house has resulted in limitations of religious and social spaces (Zhang,
2015). This limitation suggests that the development of knowledge and communication of people with tourists has encouraged people to re-order their house. Most pavilions in the house compounds (98\% of houses in Kuta, 100\% in Sanur, 65\% in Ubud and 92\% in Kamasan) had been transformed. The new structures in the compound pavilions have caused the change of some natahs ( $89 \%$ in Kuta, $63 \%$ natahs in Sanur, 88\% in Kamasan and 16\% in Ubud (Putra, Lozanovska, \& Fuller, 2017). Ocupants expalined that they have tried to deal with the new demands of the tourism economy by compromising the implementation of religious activities. The spiritual or mystical element has no longer been presumed as a part of people's present reality (Quantrill, 1974). Therefore, tourism has influenced the spiritual element of the house. This phenomenon can be exemplified by the changes to one house in Sanur, where tourism has encouraged the changes of almost all ritual spaces. In the new setting, the limitation of ritual spaces has caused some rituals, categorized as manusa yadnya, those related to human lifecycle, and pitra yadnya, those dedicated to ancestors, to be adjusted and relocated to other parts of the house.

In this house, a new pavilion, functioning as a leased office (12)), was built by demolishing the ceremonial pavilion (bale adat/ dangin, (4)) (Figures $8 \mathrm{~A}$ and $8 \mathrm{~B}$ ). For funeral processions, the natah (7) and the shrine in the natah (9)) are still important components (see Figure 8B). However, due to the absence of the bale adat, rituals to lay a corpse are performed to the bale daja (2)). Other rituals related to lifecycle ceremonies are also moved where they are no longer performed in the existing natah, but in the new natah (10) and a new pavilion (11) (Figure 8B). This space was a backyard where people performed profane activities such as raising animals, cultivating trees and processing garbage. Therefore, the penetration of tourist activities into domestic and ceremonial spaces has caused some religious activities to move into domestic spaces. To survive the economic challenge, the configuration of this house focuses on the functionality of space rather than symbolical meaning and hierarchy of space. The use of spaces in the transformed house now no longer presents spiritual symbol of ritual movements and locations.

The construction of tourist facilities has caused the gradual reduction of ceremonial spaces. This decrease or disappearance represents an erosion of the traditional house as a stage of ceremonial activities, in which the house becomes dependent on other facilities to serve its occupants. Some investigated houses, including those in Ubud, Kuta and Kamasan, are unable to accommodate some ceremonies in the houses, such as ngaben (cremation ceremony) and nyekah (purification of the soul). The houses no longer had a backyard (teba) as a place for preparation activities (Figure 9). On the other hand, the courtyard in some house, which was wide enough to perform domestic and ceremonial activities (Figure 10), has been getting smaller (Figure 11). Therefore, it is difficult for the owners to perform ngaben and nyekah ceremonies in the house. 


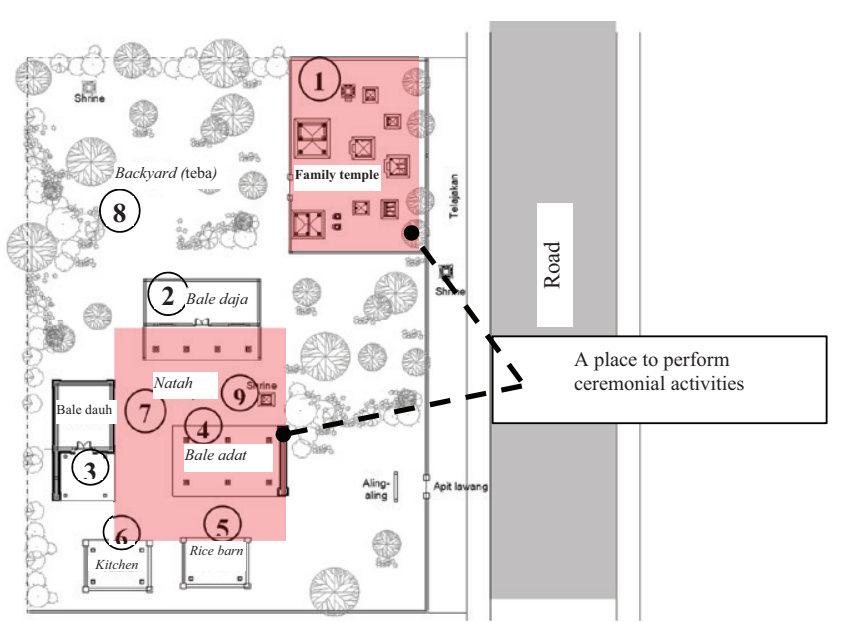

A. An existing configuration

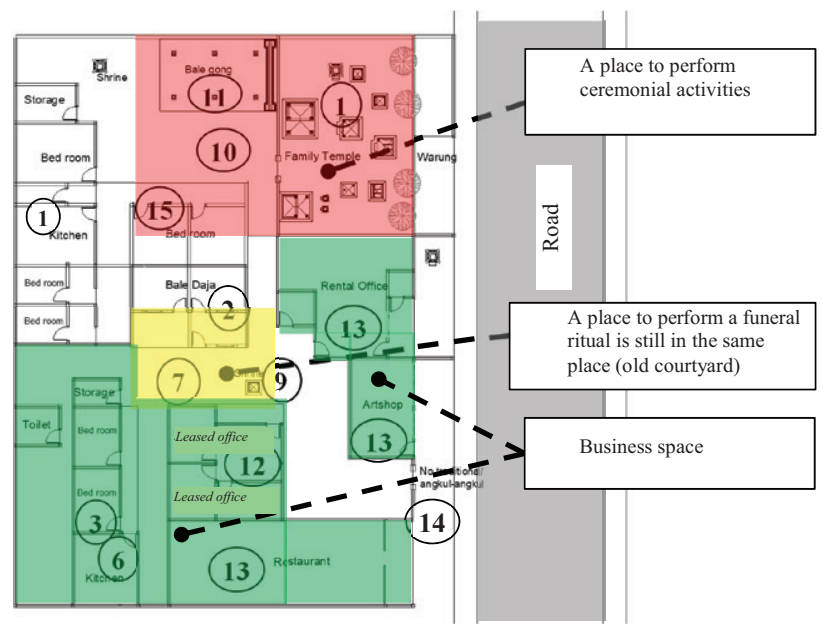

B. A transformed configuration

Figure 8 . The use of spaces in a traditional house (A). In the new setting (B), some ceremonies are relocated to other spaces (source: authors)

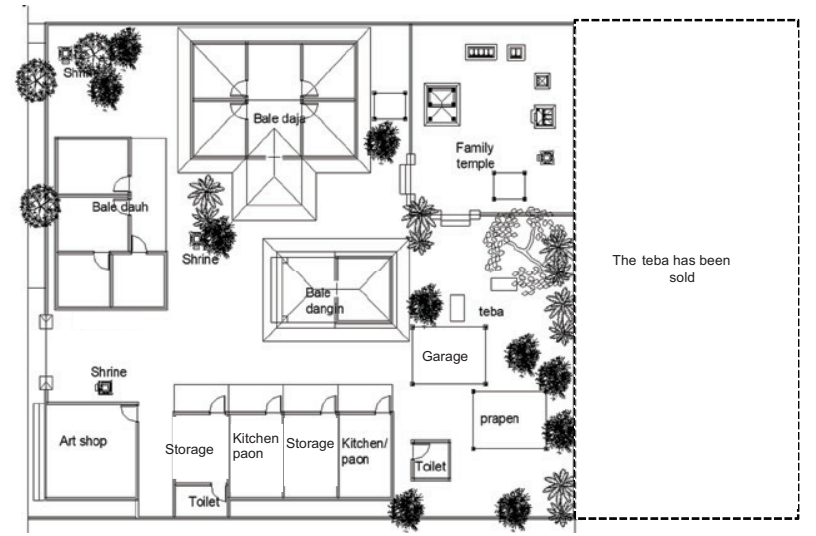

Figure 9. The house no longer had a backyard as a place for preparation of ceremonies (source: authors)

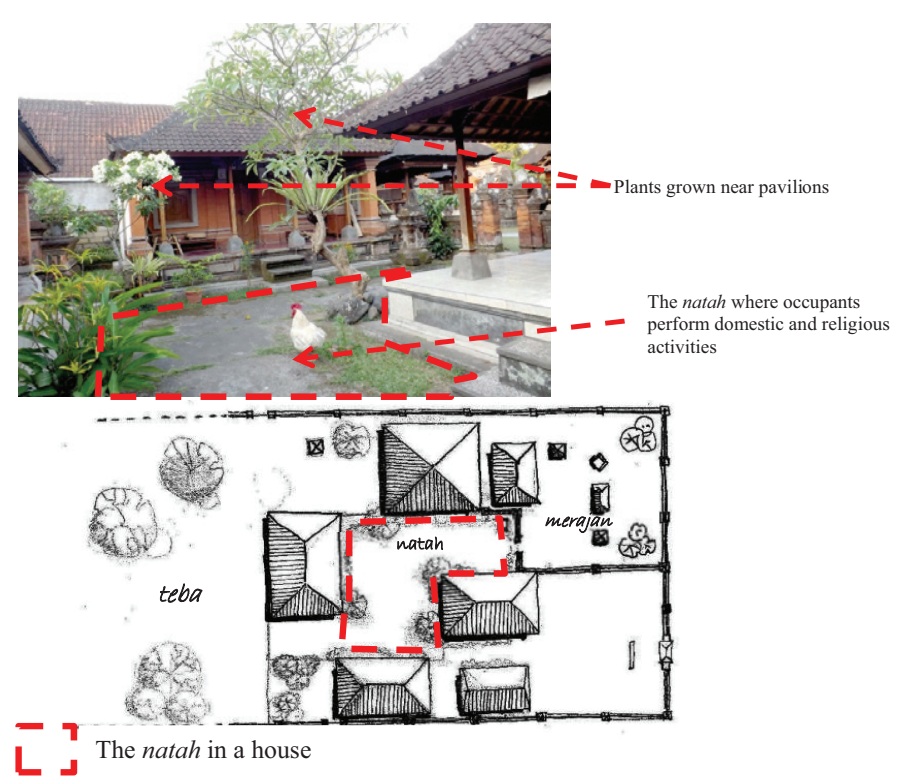

Figure 10. The traditional courtyard (natah) (source: authors)
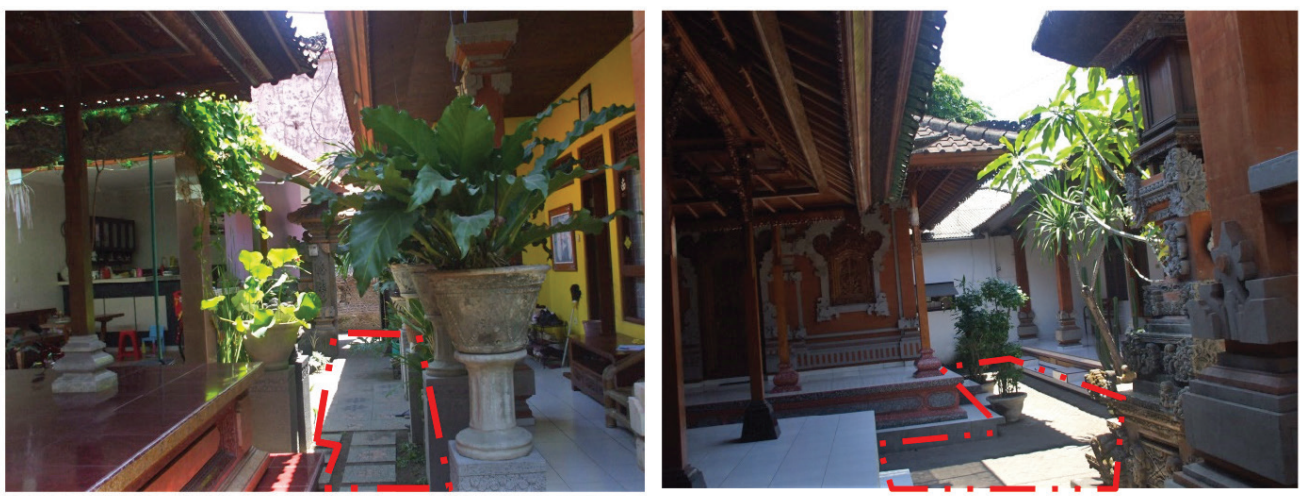

Figure 11. A courtyard (natah) that has been transformed and getting smaller (source: authors) 


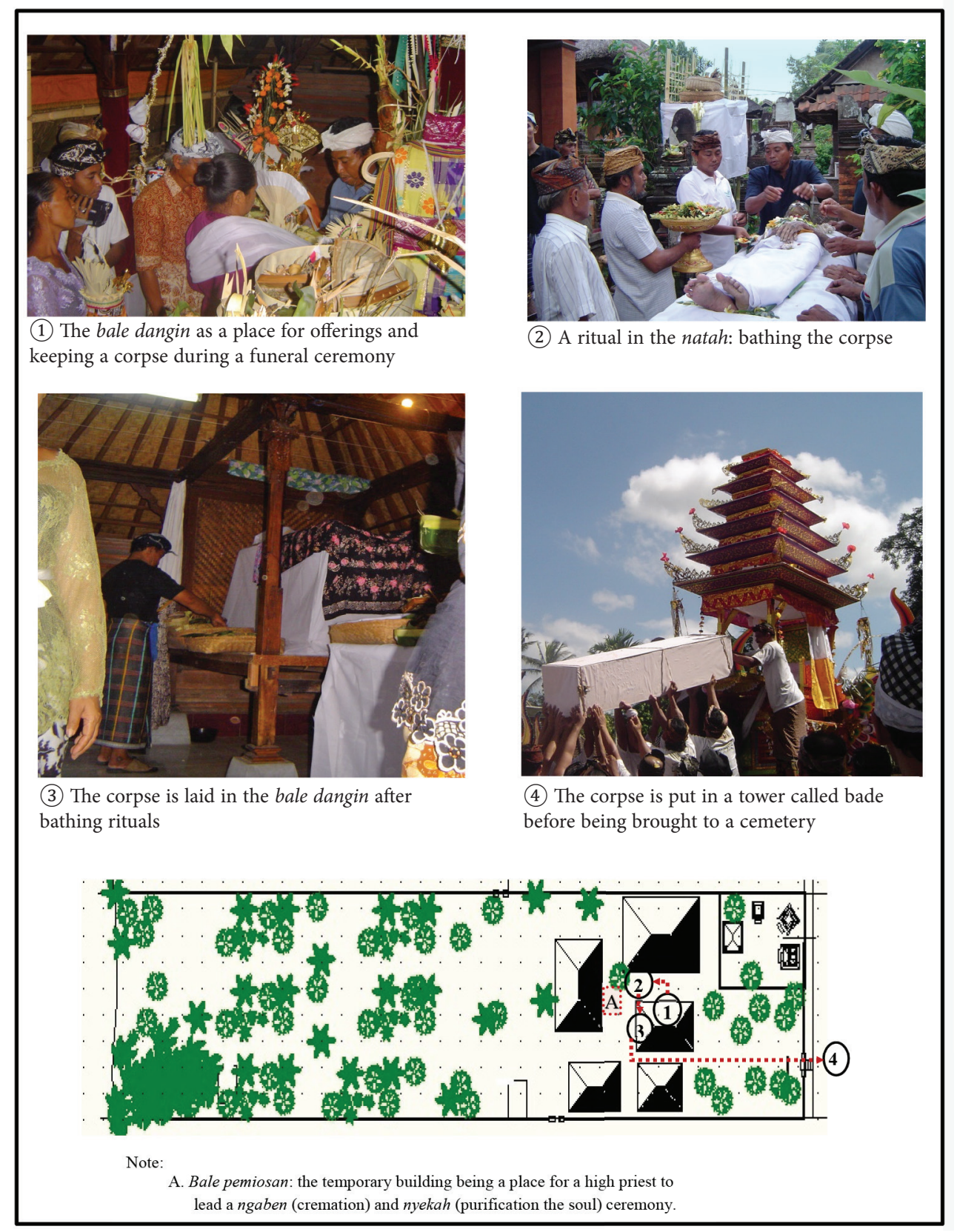

Figure 12. The use of spaces in a cremation ceremony in original setting (source: authors)

Ngaben, usually followed by nyekah, is the biggest ceremony, takes more time and money and involves more people. The ceremonies represent a religious practice and social event for an entire paternal kinship group and society to work voluntarily to prepare and perform the rituals. As a part of society, banjar (ward or hamlet) members, as a part of a village, also help the family to prepare the ceremonies. The ceremony begins from the bale dangin where the corpse is laid (1)). The corpse is then moved to the natah where many rituals, including the bathing of the corpse and praying, are performed (2)). Furthermore, the corpse is laid in the bale dangin (3) before being brought to the cemetery (4)) (Figure 12). On the day of the cremation ceremony, all families and the members of the traditional neighborhood will come to the house to witness and help the family.

However, the ngaben ceremony in the investigated houses is now performed in village facilities called $n g a-$ ben ngerit or ngaben massal. This new tradition was introduced in the 1900s (Connor, 1996) to help poor people to perform the ceremony at a lower cost without losing the significance of the rituals. Today, based on spatial stories of the occupants related to ngaben ceremonis in the house, ngaben massal is also performed by the people who have limited ritual spaces in their house as in some transformed traditional Balinese houses. Ubud, Kuta and Kamasan have regulated this tradition in their awig-awig (the written traditional rules) to become a regular ritual. 
This ritual therefore has created new social practices in the communities. Rituals, offerings and supported activities during the ceremonies are performed as usual, but the ceremony is carried out in different places. Beliefs are gradually transformed based on the demand of recent conditions in communities where "the objects to be believed" and "their mode of definition" have undergone the process of renewal (de Certeau, 1984, p. 184). The adjustment of traditions produces a new set of traditions that respond to novel situations (Shils, 1971; Hobsbawn, 1983; Clifford, 1994; Williams, 1983). The old ritual is performed in the new conditions and setting as a process of "formalization and ritualization" that refers to the past (Hobsbawn, 1983, p. 4).

The historical spatial story of the occupants have unveiled the process of cultural activities transformation. Ngaben, which was traditionally performed individually by the family with some help from village members, is now collectively performed by the members of the village facilitated by a village board. The village facilities and board have become important and have more roles than the traditional house. As a new tradition, ngaben ngerit is not created as a direct effect of tourism. However, tourism has stimulated people to refresh such religious and social practices and perform them regularly to solve people's space limitations but also to create leisure time for rituals.

Tourism has offered opportunities for the houses to create economic benefits in which the main livelihood has changed from agriculture into service and trade sectors (MacRae, 1997). However, these workplaces have formal requirements including working in particular places and regular hours, produces difficulties such as adjusting work schedules for people. Therefore, based on naratives of occupants' memory, many people stated that they do not have enough time to participate actively in the time-consuming work of traditional obligations in the traditional houses. This condition encourages the transformation of the old traditions in the house.

The limitation of spaces in the house and the availability of people's leisure time for rituals have encouraged people to perform ngaben ngerit more regularly than previously. Ubud, Kuta and Kamasan have regulated this tradition in their awig-awig (the written traditional rules) to become a regular ritual. The people can perform the ceremonies even though they have limited time and money. Working together and sharing particular offerings with other people have produced new social events in the villages.

Many activities, from preparations to main rituals, are held in the village facilities. Such rituals have produced new types of social practices whereby the village plays an important role as a central place, drawing people into revitalized rituals and traditions. Temporary bamboo structures are built in the village as places for ceremonies (Figure 13). All activities in such rituals have produced a layered sense of traditions whereby religious festivals and social festivals have become intertwined (Lozanovska, 2011). Therefore, during the ceremony, some village facilities become the busiest places, while houses have become less important and quieter places. Village facilities have been substituted for the functions of the house. The gradual disappearance of many functional structures associated with ngaben and nyekah present a real deterioration of the cultural functions of the traditional house.

\section{c. Transformation of the palemahan spaces}

A backyard (teba) is an inseparable part of the traditional house providing many materials for offerings and daily food (Covarrubias, 1974). In a small part of a teba, people also perform some preparation for ceremonies such as food for offerings or feasts. However, the transformation of the traditional house for tourist facilities has changed the function of a teba which in turn influences the preparations for these ceremonies. In the four villages, the backyards were mostly transformed to the extent that $87 \%, 85 \%, 60 \%$ and $54 \%$ in Sanur, Kuta, Ubud and Kamasan respectively (Putra, Lozanovska, \& Fuller, 2017). The backyard in the houses had insufficient space for planting trees or raising animals in which these changes decreased their traditional functions. However, $46 \%$ and $40 \%$ of the backyards in the inland villages of Kamasan and Ubud had enough space to accommodate their traditional functions.

The transformation of the house presents an architectural struggle of maintaining traditions in the house and causes the adjustment of the ceremonial preparations
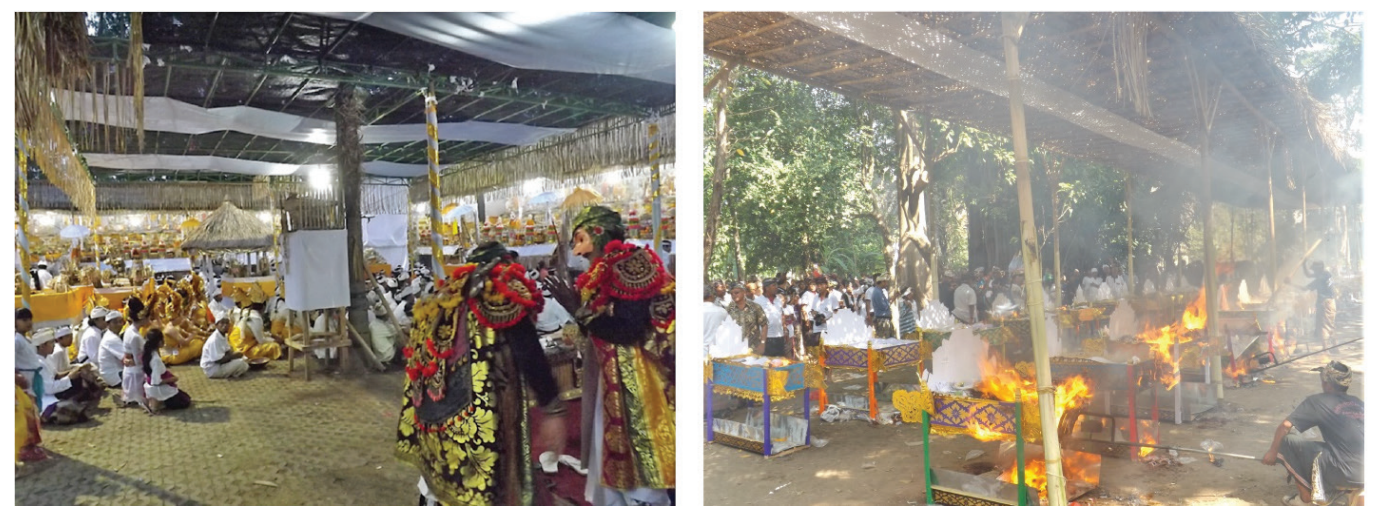

Figure 13. Temporary structures as places for ngaben ngerit (source: authors) 


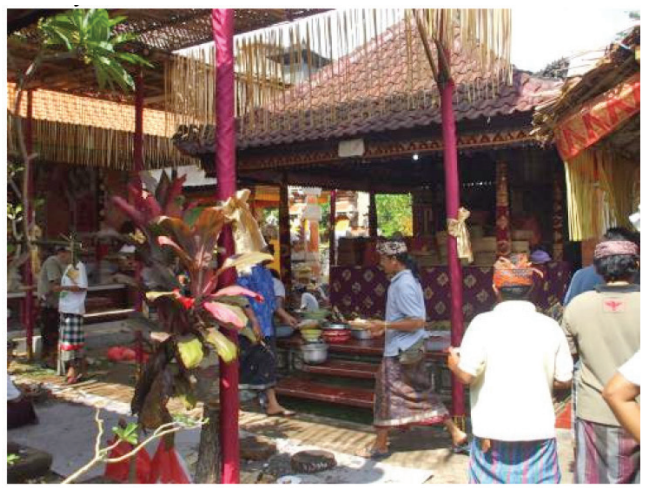

Figure 14. The preparation food moves from the backyard into the courtyard called natah (source: authors)

that involve many people. The changes were investigated through spatial and narratives of ocupants's memory in which the transformation of a teba compel people to move the activities to another place of the house such as the natah (Figure 14). The natah and the pavilions, that traditionally were places for women to prepare offerings, are now also used by men for food preparation. In this case, women and men share a space by arranging the times of preparation activities. When men prepare food, they usually need one to two days; women work on the other days.

The other alternative for food preparation is to use the village facilities. A household, helped by related families and members of a village, prepare food for feasts and offerings in the village facilities. The families bring raw materials to the village, and members of the village come to prepare the food. On completion, the food will be brought to the house, and the owner will use the food for feasts and offerings. In this case, the house no longer functions as a place for food preparation during the ceremonies. The teba also no longer has space for planting trees and raising animals for offerings. In this case, people are compelled to take the materials needed from other land or buy them in markets. This phenomenon is currently common in Bali, where people buy many kinds of materials for offerings in markets.

This phenomenon has changed the functions of the backyard. Although some transformed houses have enough spaces to plant vegetation as usual, such as $46 \%$ and $40 \%$ of the backyards in the inland villages of Kamasan and Ubud had enough space to accommodate their traditional functions (Putra, Lozanovska, \& Fuller, 2017), the vegetation is just used as an element of the garden and is often no longer used as materials for offerings. Many wild plants are dug up; raising animals and disposing of garbage are no longer possible in the house. Many flowers and fruits are planted in such a way to create an organized garden. The plants in the backyard that were materials for ceremonies now have become decorative elements to entice tourists. The teba, that was an unlived part, now becomes an artistic place where tourist accommodation is surrounded by gardens for tourist convenience.

\section{Toward more pragmatic settings}

The traditional house, as a tradition, is not something frozen but it experiences a gradual transformation ( $\mathrm{Su}-$ artika, 2013). The re-ordering of the spaces in the house presents an intimate interaction between traditional architecture and contemporary architecture adapted for tourists. However, through the proces of transformation, the house remains alive and influences people lives to day (Cuthbert, 2013). The transformation of the house focuses on the functionality of the house, rather than its spiritual meaning. The meaning of the houses in tourism villages, which is like the 'niang houses' of the Wae Rebo village described by Allerton (2003, p. 5), concerned the practicalities of life, rather than presenting genuineness. The space that was highly ordered and organized as a religious symbol is now transformed more into just a physical space. The use of space has undergone a deterioration of traditional meaning, where some ceremonial activities are now conducted in the domestic spaces. The alteration of ceremonial spaces into domestic or business spaces shows that the physical configuration has undergone an evolution of form, from ritualistic patterns into more logical or secular patterns. The re-ordering of the traditional house far from presents the essence of settings and the sense of the forms and spaces. Rather, the transformation is constrained by practices that focus on the physical configuration or decorative elements (Ivkovska, 2016). The use of space is more for practical reasons, rather than for presenting spiritual symbols of ritual spaces in the traditional house.

This transformation can be best described as an ongoing renewal. The houses are architectural practices in which they, "like material goods", can be adjusted to address the current demand of the people (Pellow, 2016, p. 76). Central to this argument is an exploration of how the traditional Balinese house is reconstructed over generations. The transformation is read as a pragmatic response to address new challenges in the community by reinterpreting the configuration of the house. This response is the challenge to architectural practice in $\mathrm{Ba}$ linese communities to maintain the traditional nuances of the house, performing not only domestic and sociocultural activities but also the additional activities of tourists. However, household domains have become public spaces as the tourism economy infiltrates the house. This infiltration has blurred architectural boundaries in the plan and functions of spaces in the traditional Balinese house. The transformed house is unable to express its original characteristics, hierarchy values and symbolic meaning related to the position and movement of rituals.

\section{Conclusions}

Transformation of the traditional Balinese house is a dynamic field where the physical configurations, religious activities, and social practices undergo continuous renewal in response to changing conditions. This paper has 
explored the conflict that exists between the conservation of the character of the traditional Balinese house and the demands of tourism. The traditional house, a place where the family's history and ancestors are located, has undergone transformation in which tourist activities infiltrate domestic and ceremonial spaces.

Spatial appropriation and reduction due to the inclusion of tourist facilities have caused the gradual disappearance of traditional elements that result in the deterioration of religious and social practices. In the new settings, rituals, especially those in the family temple, are carried out as usual. The transformation of the family temple does not alter the ritual processions including those performed on a daily, monthly and six-monthly basis. However, the sacred sense of rituals is no longer integral to the dwelling spaces of the houses, especially if the family temple has been relocated onto the upper floor. The relocation has produced a visual separation of the sacred sense of religious practices precluding the sacred to be experienced by people in other spaces in the house.

Some rituals that are categorized as manusa yadnya, the rituals that are related to the human life cycle, and pitra yadnya, the rituals dedicated to ancestors, have been adjusted and relocated. In this adjustment process, people have rationalized rituals. The transformations are far from maintaining the essence of the traditional house and the spirit of the traditions. Rather the traditions are configured and consolidated as a response to the new demands of tourist activities without considering the original meaning and spirit of spaces in the house. Therefore, the transformation can be read as a pragmatic response and reaction to address new challenges in the house. The infiltration of the tourist economy has blurred architectural boundaries and has reduced the spiritual capacity, cultural meaning and symbolic functions of the spaces in the traditional Balinese house. Therefore, the house is unable to play all of its roles independently and this affects the way that it accommodates Balinese traditions.

\section{Acknowledgements}

This paper is dedicated to Robert James Fuller who has contributed a lot of thought. He has been actively involved in completing this paper. But he passed away a few weeks before this paper was submitted.

\section{References}

Achmadi, A. (2007). The architecture of Balinisation: writings on architecture, the villages, and the construction of Balinese cultural identity in the 20th century ( $\mathrm{PhD}$ thesis). The University of Melbourne, Australia.

Allerton, C. (2003). Authentic housing, authentic culture?: transforming a village into a "tourist site" in Manggarai, Eastern Indonesia. Indonesia and the Malay World, 31(89), 119-128. https://doi.org/10.1080/13639810304440

Ashrama, B., Pitana, I. G., \& Windia, W. (2007). Bali is Bali forever, ajeg dalam bingkai tri hita karana. Denpasar: Bali Travel News and Pemerintah Provinsi Bali.
Bugnicourt, J. (1977). Tourism with no return. The Bridge, 2(4), 19-20. Clifford, J. (1994). The predicament of culture: twentieth-century ethnography, literature, and art. Cambridge: Harvard University Press.

Cohen, E. (1978). The impact of tourism on the physical environment. Annals of Tourism Research, 5(2), 215-237. https://doi.org/10.1016/0160-7383(78)90221-9

Connor, L. H. (1996). Contestation and transformation of Balinese ritual: the case of ngaben ngirit. In A. Vickers (Ed.), Being modern in Bali: image and change (pp. 179-211). New Haven: Yale University Southeast Asia Studies.

Covarrubias, M. (1974). Island of Bali. Kuala Lumpur: Oxford University Press.

Cuthbert, A. R. (2013). Vernacular transformations context, issues, debates. In G. A. M. Suartika (Ed.), Vernacular Transformations: Architecture, Place, and Tradition (pp. 7-39). Denpasar: Pustaka Larasan.

Dalem, A. A. G. R. (2007). Filosofi tri hita karana dan implementasinya dalam industri pariwisata. In A. A. G. R. Dalem, I. W. Wardi, I. W. Suarna, \& I. W. S. Adnyana (Eds.), Kearifan lokal dalam pengelolaan lingkungan hidup (pp. 81-94). Denpasar: UPT Penerbit and Pusat Penelitian Lingkungan Hidup Universitas Udayana.

Danes, P. (2001). Balinese architecture from cosmic to modern. In U. Ramseyer \& I. G. R. P. Tisna (Eds.), Bali living in two worlds (pp. 95-104). Museum der Kulturen Basel and Verlag Schwabe \& Co.AG, Basel.

de Certeau, M. (1984). The practice of everyday life. Berkeley: University of California Press.

Derek \& Japha, V. (1991). Identity through detail: an architecture and cultural aspiration in Montagu, South Africa, 1850-1915. TDSR, II (pp. 17-33).

Dogan, H. Z. (1989). Form of adjustment social impact of tourism. Annals of Tourism Research, 16(2), 216-236. https://doi.org/10.1016/0160-7383(89)90069-8

Eiseman Jr, F. B. (1989). Sekala and niskala: essays on religious, ritual and art, vol. I. Singapore: Periplus Editions.

Eisenstadt, S. N. (1973). Post-traditional societies and the continuity and reconstruction of tradition. Daedalus, 102(1), PostTraditional Societies (Winter, 1973), 1-27. The MIT Press on behalf of American Academy of Arts \& Sciences.

Ekhaesa, E. N., Amole, B., \& Martins, O. I. (2018). Prefiguring house in a traditional city: a case for Benin house types and characteritics. Journal of Architecture and Urbanism, 42(1), 1-15. https://doi.org/10.3846/20297955.2014.994810

Geertz, C. (1973). The interpretation of cultures. New York: Basic Books Inc.

Geertz, C. (1984). Negara: the theatre state in nineteenth-century Bali. New Jersey: Pricenton University Press.

Gelebet, I. N. (1986). Arsitektur tradisional daerah Bali. Denpasar: Departemen Pendidikan dan Kebudayaan.

Geriya, I. W. (2007). Konsep and strategi revitalisasi kearifan lokal dalam penatan lingkungan hidup daerah Bali. In A. A. G. R. Dalem, I. W. Wardi, I. W. Suarna, \& I. W. S. Adnyana (Eds.), Kearifan lokal dalam pengelolaan lingkungan hidup (pp. 52-60). Denpasar: Penerbit Universitas Udayana.

Grunewald, Rd. A. (2002). Tourism and Cultural Revival. Annals of Tourism Research, 29(4), 1004-1021. https://doi.org/10.1016/S0160-7383(02)00005-1

Gusfield, J. R. (1967). Tradition and modernity: misplaced polarities in the study of social change. American Journal of Sociology, 72(4), 351-362. https://doi.org/10.1086/224334

Hall, S. (1990). Cultural identity and diaspora. In J. Rutherford (Ed.), Identity, community, culture difference (pp. 222-237). London: Lawrence and Wishart. 
Hanna, W. A. (1972). Bali in the seventies, part I: cultural tourism. American Universities Field Staff Reports. Southeast Asia Series, 20(2), 1-7.

Harvey, K. (2014). Economy and the eighteenth - century house: A cultural history of social practice. Home Cultures, 11(3), 375390. https://doi.org/10.2752/175174214X14035295691193

Hitchcock, M., King, V. T., \& Parnwell, M. J. G. (1993). Tourism in South-East Asia. London: Routledge.

Hobart, A., Ramseyer, U., \& Leemann, A. (1996). The people of Bali. Massachusetts: Blackwell Publishers Ltd.

Hobart, M. (1978). The path of soul: the legitimacy of nature in Balinese conceptions of space. In G. Milner (Ed.), Natural symbols in South-East Asia (pp. 5-28). London: School of Oriental and African Studies.

Hoben, A. \& Hefner, R. (1991). The integrative revolution revisited. World Development, 19(1), 17-30. https://doi.org/10.1016/0305-750X(91)90034-F

Hobsbawn, E. (1983). Introduction: inventing traditions. In E. Hobsbawn \& F. Ranger (Eds.), The invention of tradition (pp. 1-14). Cambridge: Cambridge University Press.

Ivkovska, V. (2016). Reinventing vernacular traditions to reveal national identity: A case study of the "Macedonian Village". TDSR, XXVII(II), 71-83.

Kusno, A. (2000). Behind the postcolonial: Architecture, urban space and political cultures in Indonesia. London: Routledge.

Kusno, A (2010). The end of the peasantry and the politics of periurbanization in an Indonesia metropolis. Singapore: Asia Reseach Institue Working Paper Series no 139.

Lansing, J. S. (1983). The "Indianization" of Bali. Journal of Southeast Asian Studies, 14(2), 409-421.

https://doi.org/10.1017/S002246340001105X

Logan, W. S. (1994). Hanoi townscape: symbolic imagery in Vietnam's capital. In Askew \& W. S. Logan (Eds.), Cultural identity and urban change in Southeast Asia: interpretative essays (pp. 43-69). Geelong: Deakin University Press.

Lozanovska, M. (2002). Architectural frontier/ spatial story: the problematic of representing the everyday. Space and Culture, 5(2), 140-151. https://doi.org/10.1177/1206331202005002006

Lozanovska, M. (2011). Holy days after migration. 2nd International Conference on Intangible Culture (pp. 459-469). Green Lines Instituto, Barecelos.

MacRae, G. S. (1997). Economic, ritual and history in Balinese tourist town (PhD thesis). University of Auckland.

MacRae. (2011). Negotiating architecture worlds in Indonesia: the work of Eko Prawoto. The Copenhagen Journal of Asian Studies, 29(1), 92-119. https://doi.org/10.22439/cjas.v29i1.4022

Mantra, I. B. (1993). Bali masalah sosial budaya dan modernisasi. Denpasar: Upada Sastra.

McKean, P. F. (1973). Cultural involution: tourists, Balinese, and the process of modernization in an anthropological perspective (PhD dissertation). Brown University.

McLendon, A. E. (2013). Leap and Shout, Ye Living Building, ritual performance and architectural collaboration in Early Shaker Meeting houses. Buildings and Landscapes, 20(2), 48-76. https://doi.org/10.5749/buildland.20.2.0048

Nas, P. J. M. (1997). The image of Denpasar: interaction between tradition and tourism. In Pfeffer, G. \& Behera, D. K. (Eds.), Contemporary Social Society Tribal Study, 2, 345-371. Development Issues Transition and Change. New Delhi: Concept Publishing Company.

Nas, P. J. M. (1999). Design and meaning of architecture and space among ethnic groups of Western Indonesia. In Ethnic Identity in Urban Architecture. Generation of Architects in Banda Aceh. Leiden: Leiden University.
Nas, P. J. M. (2012). The urban anthropologist as flâneur: The symbolic pattern of Indonesian cities. Wacana, 14(2), 429-454.

Nordholt, H. S. (1986). Bali: colonial conceptions and political change 1700-1940 from shifting hierarchies to "fixed" order. Rotterdam: Erasmus.

Oliver, P. (1998). Encyclopaedia of vernacular architecture of the world, vol. 1. Cambridge: Cambridge University Press.

Orlando, R. V. (2014). Reediting the architectural past, a comparison of surviving physical and documentary evidence on Marykands Eastern Shore. Buildings and Landscapes, 21(2), 88-112. https://doi.org/10.5749/buildland.21.2.0088

Pellow, D. (2016). Multiple modernities: Kitchens for an African elite. Home Cultures, 12(1), 55-82. https://doi.org/10.2752/175174215X14171915160290

Picard, M. (1996). Bali: cultural tourism and touristic culture. Singapore: Archipelago Press.

Picard, M. (2003). Touristification and Balinization in a time of reformation. Indonesia and the Malay World, 31(89), 108-118. https://doi.org/10.1080/13639810304435

Proshansky, H. M., Fabian, A. K., \& Kaminoff, R. (1983). Place identity: physical world socialization of the self. Journal of Environmental Psychology, 3, 57-83. https://doi.org/10.1016/S0272-4944(83)80021-8

Puja, I. G. N. A. (1986). Arsitektur tradisional daerah Bali. Denpasar: Departemen Pendidikan dan Kebudayaan.

Putra, I. D. G. A. D., Lozanovska, M., \& Fuller, R. (2013). The transformation of the traditional Balinese house for tourist facilities: managing a home-based enterprise and maintaining an architectural identity. Journal of Asia pacific Management and Business Aplication, 2(2), 53-67.

Putra, I. D. G. A. D., Lozanovska, M., \& Fuller, R. (2017). A methodology to evaluate the transformation of the traditional Balinese house as a consequence of tourism. International Journal of Architecture Research (Archnet-IJAR), 11(1), 83100. https://doi.org/10.26687/archnet-ijar.v11i1.1134

Quantrill, M. (1974). Ritual and response in architecture. London: Lund Humphries Publishers Limited.

Rapoport, A. (1969). House, form and culture. Englewood Cliffs: Prentice Hall Inc.

Rapoport, A. (1983). Development, culture change and supportive design. Habitat International, 7(5/6), 249-268. https://doi.org/10.1016/0197-3975(83)90076-0

Redfield, R. (1965). Peasant society and culture. Chicago: University of Chicago Press.

Sanger, A. (1989). Music and musicians, dance and dancers: sociomusical interrelationships in Balinese performance. Yearbook for Traditional Music, 21, 57-69. https://doi.org/10.2307/767768

Shils, E. (1971). Tradition. Comparative Studies in Society and History, 13(2), Special Issue on Tradition and Modernity, 122159. https://doi.org/10.1017/S0010417500006186

Shils, E. (1981). Tradition. London: Faber and Faber Limited.

Sparkes, S. (2003). Introduction: the changing domain of the house in Southeast Asia. In S. Sparkes \& S. Howell (Eds.), The house in Southeast Asia: a changing social, economic and political domain (pp. 1-15). London: Routledge Curzon.

Suartika, G. A. M. (2013). Introduction. In G. A. M. Suartika (Ed.), Vernacular Transformations: Architecture, Place, and Tradition (pp. 1-5). Denpasar: Pustaka Larasan.

Suprapti, A., Kistanto, N. H., Pandelaki, N. H., \& Indrosaptono, D. (2017). Control of spatial protection in Kauman Semarang. Journal of Architecture and Urbanism, 41(4), 268-277. https://doi.org/10.3846/20297955.2017.1402717

Swellengrebel, J. L. (1984). Introduction. In J. L. Swellengrebel (Ed.), Bali: studies in life, thought, and ritual (pp. 1-76). Nethelands: Foris Publication Holland. 
Tan, R. Y. D. (1967). The domestic architecture of South Bali'. Bijdragen tot de Taal-, Land-en Volkenkunde, Koninklijk Instituut voor Taal-, Land-en Volkenkunde, 123(4), 442-475. Leiden. https://doi.org/10.1163/22134379-90002891

UNESCO. (1982). Mexico city declaration on cultural policies. Mexico City: World Conference on Cultural Policies.

Vale, L. J. (1992). Architecture, power, and national identity. New Haven \& London: Yale University.

Vickers, A. (1989). Bali: a paradise created. Ringwood Victoria: Penguin Books Australia Ltd.

Wijaya, M. (Michael White). (2003). Architecture of Bali: a sourcebook of traditional and modern forms. London: Thames and Hudson.

Williams, R. (1983). Culture and society: 1780-1950. New York: Columbia University Press.
Wood, R. E. (1993). Tourism, culture and the sociology of development. In K. Hitchcook \& Parnwell (Eds.) (pp. 48-70). London: Routledge.

Yang, L. \& Wall, G. (2009). Ethnic tourism: a framework and an application. Tourism Management, 30, 559-570. https://doi.org/10.1016/j.tourman.2008.09.008

Yang, L., Wall, G., \& Smith, S. L. J. (2006). Ethnic tourism development: Chinese Government perspectives. Annals of Tourism Research, 35(3), 751-771. https://doi.org/10.1016/j.annals.2008.06.005

Zhang, D. (2015). Courtyard houses of Beijing: Lessons from the renewal. TDSR, XXVII(I), 69-82. 